\title{
Action, objective, intersubjectivity: towards a theory of social action
}

Francesco Forlin (Università degli Studi di Perugia)

The reflection on intersubjectivity is a central question in the contemporary philosophical debate. In this field, current practical philosophy faces one of the most difficult challenges. Apparently, the research for a foundation of the intersubjective level seems to lead inevitably towards the abandonment of the logical-foundation theory on which the philosophy had been based up until Hegel. Thus, for example, there are those who have observed that it is possible to approach the subject of intersubjectivity only if beginning from "an understanding of the society in terms of communication, in other words, in terms of dialogue relations" [Cortella 1995, 200]. If that were so, the need would arise to attribute every social theory to a consideration of language, developing in this way an intersubjective constitution founded on mechanisms that are dialogic-communicative rather than logical-rational. In fact, this is the approach taken by the mojority of post-Hegelian practical continental philosophy. In this report, however, I would like to attempt something different. That is, I would like to explore the possibility of inserting the subject of intersubjectivity right into the heart of Hegelian thinking, with an aim to outline the foundation of a social action theory capable of exhibiting reasons stronger than those deriving from simple dialogic validation.

I am convinced that it is essential to avoid understanding intersubjectivity as something irreflexive; this is a risk, as V. Hösle writes, contained between the folds of the "dialogic" positions. Even the intersubjective level must, like every other level of reflection, find good logicalrational coverage. This is the great gamble of German idealism, and of Hegel in particular. The problem arises from the fact that, to quote Hösle again, "real Hegelian philosophy is not completely covered by logic" [Hösle 2012, 790], so that, if , in a Hegelian fashion, the primacy of logic is assumed, we find ourselves faced with an open task that is, in some way, requested by the deep spirit of Hegelian thinking - that is to say: the foundation of intersubjectivity without, however, having the tools to resolve it. This, in my opinion, is a practical reflection which intends to proceed with Hegel beyond Hegel. Now, the difficult correspondence between the ideal level and the real level is the starting point from which the problem of the relationship between intersubjectivity and logic emerges. Reflection on intersubjectivity, in fact, is dominated by the in-depth anlaysis of the dynamics of recognition (die 
Anerkennung), which evidently require the subject of intersubjectivity be taken into consideration. Reflection on logic, however, would seem to be mainly pivot on the idea of the "solitary" self-development of the absolute.

But is such a distance real? It may be useful to remember how, for Hegel, the Absolute, as a subject, is always structured according to a Beziehung in which a Verdopplung takes place, capable of placing it in Beziehung auf sich selbst so as to be able to be found as das Andere seiner selbst an ihm selbst.

This means that for Hegel reflection is never really anything different with respect to the communication-relationship. That space which, in traditional logic, separates the subject and predicate in the judgement, appears, in Hegelian logic, put into motion and rethought. M. Theunissen writes: "verschwindet vorab das traditionell verstandene Subjekt, das hypokeimenon, jedoch so, dass es durch eine anders verstandene Subjektivität substituiert wird, die nun beide Seiten besetzt, auch die des ehemaligen Prädikats" [Theunissen 1994, 458]. Such a subject is a subject which is tightly bound to the idea of Bewegung, of motion. It implies the rethinking of the function - care must be taken: which is purely logical - of the copula, which is not lmited to uniting the terms of the judgement, but to indicating a task which the subject and predicate must carry out, whence the idea of motion. In this sense, the assumption of the predicate in the subject, far from implying the simple identification of both, rather indicates a deformity which Hegel transforms into a sort of dialectical engine. However, if we do not want such a dialectic to remain purely inside the subject, so that the Verdopplung which takes place in the subject is genuinely real, it is necessary to talk about a subject which has the abilty to come out of itself to then recover. This, very briefly, is the dialectical motion which Hegel discusses regarding judgement. This, at the same time, is the only way that the development of the subject does not end up presenting itself as being "solitary". The space of actual otherness which is required as the subject can really find himself again opens up, perhaps, the area of thinkability of an authentic other-than-self which could be a basis for the topic of intersubjectiviy.

It is possible to follow this common thread in the Hegelian treatise of the nature of the subject, since Hegel names such a subject Geist. The treatise of the topic of the eventual foundation space of intersubjectivity is, therefore, transformed into a discussion on the nature of the Hegelian Geist. First of all, it must be said that, as far as the logical structure of judgement is concerned, the Geist's action is present not as much in the subject, as in the copula [Theunissen 1994, 456]: in the latter, in fact, the logical translation of the constitutive activity of the Absolute itself is expressed. From this point of view, contrary to what is maintained by J. Habermas and A. Honneth, it is possible to maintain that in the Urteilslehre contained in the Wissenschaft der Logik from 1816 that idea of opening to the Jena philosophy of the spirit is still present. In the Wissenschaft der Logik, in fact, the oscillator dynamics between subject 
and predicate in the judgement is revealed as a recognition dynamics, the intersubjective form of transformation of the immediate future, since, as it finally emerged in the doctrine of the Syllogism, the copula shows, in its logical universality, that which, on a practical level, it is possible to interpret as the continuation of the individual in other individuals. The same occurs also in the young Hegel's philosophy of the Spirit, whose characterization in an intersubjective sense was made well known by J. Habermas and A. Honneth. The latter, in particular, is very clear in stating that the distance between the young Hegel and the mature Hegel consists in the different comprehension of Geist [Honneth 2002, 40]. On one hand, there would be the Geist understood as a path of development of the power of the self in the System der Sittlichkeit of 1802; on the other, starting from at least the Phänomenologie des Geistes, the Geist as a means of social constitution, of resolution of otherness of the two types of self-consciousness concerned Intersubjectivity, safeguarded in the first case as a place of comfort and the interlocution of two reciprocally irreducible subjects, in the second case would be scarificed according to the edification of an institutionalized community. The institutional dimension is, according to Honneth, the place of oblivion and distortion of the intersubjective dynamics: precisley in this place, the Geist, whose activities are capable of weakening and overruling the Verdopplung, would rise. In saying this, Honneth renounces exhibiting the logical translation of such a Geist, since, as it has briefly been said, in writings in youth as well as in maturity the clearest logical transposition of the activity in the Geist occurs in the case of the judgement, where such activity is never associated with the subsumption of the predicate in the subject - what implies Honneth's criticism of the community- but with the reconciliation of the copula which does not suppress the distinction. Not by chance, Honneth chooses to bluntly expunge the logic of his debate, attributing the growing importance which Hegel gave to the problem of logical foundation of the sytem as the main cause of the failure of his initial project. Nevertheless, inserting intersubjectivity into the fulcrum of the Hegelian system, rather than confining it to the phase in which Hegel's thinking still appears to be immature, in my opinion is an undeniable requirement, also because it has the quality of taking seriously the ontologically relational dimension of the Hegelian Absolute.

Let us return to reflecting upon the Geist. Differently from Theunissen, Honneth and Hösle agreee in affirming the Geist's insufficiency in the face of the necessity to structure the Ich-Du relationship: the latter, to be real, requires in the first place an exit from the setting of the Geist as self-mediation carried out by the subject. Such an exit, if for Honneth is configured as taking leave from the logical fundamentals of Hegelism and reflection on the sociopolitical dynamics of recognition, for Hösle leads to the theorization of the Liebe dimension, present above all in the Vorlesungen über die Philosophie der Religion, in the specific form of the God-man relationship present in 
Christianity, the unique authentic subject-subject relationship discussed by Hegel. In my opinion, it is possible to reiterate the importance of Liebe in Hegel, observing how the implicit plurality of subjects in the loving dynamics is already present between the folds of logic [see: McTaggart, McTaggart 1910]. The logos for Hegel, in fact, is that which is not only capable of creating relationships, but which can continuously breed new and free determinations [Houlgate 2006]. Just like the Geist, the logos itself is a collective endeavour. From here is the transition to what R. Pippin defines as theroy of social action as a practical translation of the logical achievement of the relationship [see: Pippin 2008]. Beginning with the treatise of inner (das Inneres) and outer (das Äußeres) in the Phänomenologie des Geistes (see: Pippin 2008, 150) he observes how the action, for Hegel, does not belong to the agent, since it implies the transition to a social dimension that is, of the exteriority, which, alone, makes it recognizable and readable as deed. The act's exit from itself is however duplicate: on one hand, in fact, it shows the indissolubility of the connection between action and fact. On the other hand, it shows how «the deed is essentially out there for others».

The action is configured as an opening to intersubjectivity. In other words, my freedom, in order to be actual, needs the freedom of others. This means that the recognition (Anerkennung) takes place on two levels. Firstly, the practice of my freedom passes through the experience of the freedom of others which, once recognized, it alone, can, in turn, recognize me as being free.

In the Phänomenologie, we first experience freedom in an attempt to subjugate the other - freedom as domain - which is followed by conflict (der Kampf um Anerkennung) and then relation. Of the latter there are two possible readings. The first, which has more than all helped to discredit Hegel with our contemporaries, is what might be called romantic, according to which the finite is called to become infinite. The second, which I am trying to explain here, according to which the finite is instead likely to remain as such in the intersubjective relationship in which the Absolute itself is.

The Absolute, as Geist, is therefore to be made an object of recognition in the moment in which it reveals itself to be a relational tie of a social nature. The social structures through which human relationships are formed are transformed into something more than the form of the objective spirit, on which Honneth's criticism is concentrated, and they become a place for intersubjective meeting. The two aspects, in reality, are tightly tied to each other. Geist and Liebe are, in some measure, difficult to separate.

Feedom coincides with the ever sprouting life of the Spirit, and thus it is realized in a constant Befreiung which is nothing other than the act of thinking the Necessity with which Hegel, in The Encyclopedia of the Philosophical Sciences, seals the transition, within Logic, from the Doctrine of 
the Essence to the Doctrine of the Concept. This act consists of the reconjunction of One with Oneself in the Other.

This transition, which Hegel himself described as the most arduous, is of capital importance. Hegel, although speaking about "contingency of sentiment" (Zufälligkeit der Empfindung), explains also how the same liberation "considered as sentiment, is love" (als Empfindung Liebe). Love is the modality through which one can experience the fact that "die selbstständige Wirklichkeit gedacht werden soll, als in dem Übergehen und der Identität mit der ihr andern selbstständigen Wirklichkeit, allein ihre Substantialität zu haben” (Hegel 1989, §159). For this reason to truly love is difficult, because the difficulty of love reflects the notional difficulty in which one chances upon the thought when one intends to understand the truth of the intertwining movement of the spirit so that, therefore, even the Concept is the most arduous and difficult thing because it is exactly this identity.

At this point it is evident how the relationship between Liebe and Geist reveals the deeepest of cross-references, to the point that one could say that love is the emotional-sentimental translation of that circle between essences which the concept reveals on a purely logical level and which, in the Geist, is expressed as an ability of supreme gift-of-oneself.

For this reason, in the above mentioned transition from the Essence to the Concept in the Science of Logic, Hegel writes that the concept is the realm of subjectivity or of freedom [Hegel 2011, 646]. The underlining of the very close relationship between Begriff - Freiheit - Geist - Liebe could not be clearer ${ }^{1}$.

The Spirit, just like love, «gewinnt seine Wahrheit nur, indem er in der absoluten Zerrisenheit sich selbst findet» [see: Hegel 1986], and it is much greater «aus je grösserem Gegensatze er in sich zurückkehrt» [Hegel 1986, 189].

Social action thus becomes the place of affirmation of the third party (the Spirit) which works in the relationship between the two, but since the only tie which it creates is a tie of love, its effectiveness is not expressed in selfaffirmation, but in the willingness to renounce onself, to come out of oneself which each of the two subjects is called to do in the moment in which they are on the point of recognizing the free - and therefore personal and subjective nature of the other-than-self.

\footnotetext{
${ }^{1}$ Franco Chiereghin writes: "In love, in fact, the entirety of my feeling and of my desire permeates itself with the feeling and desire of the other and, likewise, every thought and desire of the other penetrates me entirely, so that everyone finds another of himself in the other. This does not mean that everyone's own individuality sinks into an undifferentiated identity, on the contrary: love, in its authenticity, cannot not love in the other the most precious thing that he has, his freedom. That which every person loves and guards in the other is therefore his freedom and in the freedom of the other he finds his own freedom which is loved and guarded in the same way. For this reason, freedom, since it is encountering oneself in the other, is, in the sentiment, love" [Chiereghin 2011, 99].
} 
The most profound reality of the Spirit eminently expresses this dynamic in Hegel: the Spirirt is He who conquers his own truth, only provided that he passes through absolute disintegration. The Spirit, therefore, can live only by dying. In the dialectic of recognition, the subject is therefore called to experience death. The death of a subject is not however to be understood in the form of pure self-destruction: it is, rather, the event which opens up the space to the recognition of the other. If, therefore, it is true that it is the Spirit that is, the Absolute Subject - who presides over the entire process, acting as a third mediator, it is also true that the recognition consists of the opening which the first subject directs to a second subject.

From here comes the intersubjective foundation of social action which, in my opinion, does not only not limit the I-you relationship to the internal dialectic of the Absolute Subject, but it actually elevates it to a place of consecration of single selfhoods - which in themselves end up being reciprocally recognized as such - as well as of the irreducibilty of these with regards to the Spirit itself. The mediation action of the latter, in fact, hangs onto, so to speak, the two subjects' free acknowlegement of the renouncement which opens the space of recognition.

Such recognition, after all, amounts to the possibility of the community dimension, which reallocates the subjects, which passed the acid test of the voluntary renouncement of oneself, within a future development in which the two relations finally appear transfigured by the actions of the third party.

It is therefore possible, as Hösle believed, that Hegel himself did not take this aspect of the profound dynamics of his thought too seriously, and that he had not prepared the notional categories to be able to think about it in depth. Nevertheless, the theoretical foundations of intersubjectivity, brought back to its Hegelian roots, is the fundamental cornerstone upon which to build the logical-rational foundations of social action.

\section{Literature}

Chiereghin, F. 2011. Rileggere la Scienza della Logica di Hegel. Rome: Carocci.

Cortella, L. 1995. Dopo il sapere assoluto. L'eredità hegeliana nell'epoca postmetafisica. Milan: Guerini e Associati.

Hegel, G. W. F. 1986. Vorlesungen über die Philosophie der Geschichte. Frankfurt a. Main: Suhrkamp.

Hegel, G. W. F. 1989. Enzyklopädie der philosophischen Wissenschaften im Grundrisse. Frankfurt a. Main: Suhrkamp.

Hegel, G. W. F. 2011. Scienza della Logica. Trans. C. Cesa. Bari: Laterza.

Honneth, A. 2002. Lotta per il riconoscimento. Trans. C. Sandrelli. Milan: Il Saggiatore.

Hösle, V. 2012. Il sistema di Hegel. Napoli: La Scuola di Pitagora. 
Houlgate, S. 2006. The Opening of Hegel's Logic. West Lafayette: Purdue University Press.

McTaggart, J., McTaggart, E. 1910. A Commentary on Hegel's Logic. Cambridge: Cambridge University Press.

Pippin, R. B. 2008. Hegel's Practical Philosophy: Rational Agency as Ethical Life. Cambridge: Cambridge University Press.

Theunissen, M. 1994. Sein und Schein. Berlin: Suhrkamp. 
Francesco Forlin (Università degli Studi di Perugia)

\title{
Action, objective, intersubjectivity: towards a theory of social action
}

\begin{abstract}
The reflection on intersubjectivity is a central question in the contemporary philosophical debate. In this field, current practical philosophy faces one of the most difficult challenges. Apparently, the research for a foundation of the intersubjective level seems to lead inevitably towards the abandonment of the logical-foundation theory on which the philosophy had been based up until Hegel. In this report, however, I would like to attempt something different. That is, I would like to explore the possibility of inserting the subject of intersubjectivity right into the heart of Hegelian thinking, with an aim to outline the foundation of a social action theory capable of exhibiting reasons stronger than those deriving from simple dialogic validation.

It is possible, as Hösle believed, that Hegel himself did not take this aspect of the profound dynamics of his thought too seriously, and that he had not prepared the notional categories to be able to think about it in depth. Nevertheless, the theoretical foundations of intersubjectivity, brought back to its Hegelian roots, is the fundamental cornerstone upon which to build the logical-rational foundations of social action.
\end{abstract}

Keywords: Hegel, intersubjectivity, social action

Ethics in Progress (ISSN 2084-9257). Vol. 4 (2013). No. 2. pp. 55-62. 